Forthcoming in: The British Journal of Politics and International Relations (2019)

Pre-proof draft copy - the final version may differ in some minor respects

\title{
Brexit, CANZUK, and the Legacy of Empire
}

\author{
Duncan Bell (Cambridge) and Srdjan Vucetic (Ottawa)
}

\section{Introduction}

The 2016 United Kingdom European Union membership referendum triggered a feverish debate over the future of the country and its role in the world. Critics of Brexit warn of a Britain stripped of much of its international influence, a country reduced to a pale shadow of its former self. ${ }^{\mathrm{i}}$ Advocates of Brexit, in contrast, paint a rosy picture. British "independence," they proclaim, will allow a muchneeded reconfiguration of public policy. Rather than a retreat into isolation or obscurity, it marks the beginning of a new phase in British engagement with the world, an opportunity to establish, in Theresa May's vacuous phrase, a “Global Britain” (Daddow, 2018).

The Brexiteers are themselves divided about how best to achieve this ambition. Beyond disagreeing over Britain's future relationship with the EU, they clash over the trading arrangements to pursue, the alliances to forge, and the kind of state that Britain should aspire to become. A number of prominent Brexit supporters have endorsed the idea of CANZUK, a union (or alliance or pact) of Canada, Australia, New Zealand, and the United Kingdom. They claim that since these countries already have so much in common, and because they are already bound together by a dense web of security commitments, it is viable to create a globe-spanning zone of free movement of goods, services, and 
labour. Others argue that these initial steps should be followed by deeper integration, even the creation of a transcontinental (con)federal polity.

CANZUK is promoted by a small but well-connected range of policy-makers, journalists, business leaders, and politicians. So far, the idea has appealed chiefly to British and Canadian Conservatives, though it has also been endorsed by the Act New Zealand Party, and, in Australia, a former prime minister, a former High Commissioner to the UK, and at least one current Senator. Its supporters have developed a loose transnational advocacy network, establishing grassroots campaigning organizations, publishing policy documents, creating social media platforms, and recruiting prominent intellectual entrepreneurs to proselytise the idea. The array of economic, political, social, and cultural connections within the English-speaking — and also white majority—world that CANZUK supporters cherish is mirrored in the dynamics of CANZUK advocacy.

This article analyses CANZUK as an attempt to develop a fruitful post-Brexit imaginary (AdlerNissen, Galpin, and Rosamond, 2017) and as a case of contemporary transnational elite advocacy (Keck and Sikkink, 1998). We begin by placing CANZUK in the context of wider debates over the "Anglosphere." Building on this discussion, and also on interviews and correspondence with key CANZUK proponents, we then map the CANZUK advocacy network. ${ }^{\text {ii }}$ Next we examine past plans for uniting English-speaking polities, tracing the idea back to late nineteenth century debates over settler colonialism. We show that the argumentative moves, institutional prescriptions, and rhetorical strategies, of CANZUK advocacy echo those of late Victorian and Edwardian imperial enthusiasts to a remarkable degree. We end by sketching some reasons to be sceptical about CANZUK. We also suggest that it cannot escape its historical origins: the empire continues to exert a powerful magnetic pull. CANZUK is a revealing symptom of some of the principal concerns animating debate over postBrexit foreign policy. 


\section{CANZUK and the Anglosphere}

Following the collapse of the Berlin Wall, elites throughout the West scrambled to develop workable visions of the coming era. Arguments for unifying or co-ordinating the Anglosphere formed part of the general intellectual tumult (Bell, 2016; Vucetic 2011). The general idea was not new - in the past, plans for unifying "Anglo" countries had travelled under various rubrics, including Greater Britain, the Anglo-Saxon race, and the English-speaking peoples. During the 1990s the idea was reanimated. The phrase Anglosphere was first coined, appropriately enough, in a science fiction novel: Neal Stephanson's cyberpunk fable The Diamond Age (1995). Since then, and especially in Brexit-era Britain, the Anglosphere has become common political currency (Kenny \& Pearce, 2018, ch. 6).

Three basic models of the Anglosphere have been invoked. They differ principally along two dimensions: geographical scope and degree of institutionalization. The most capacious (and vaguest) model envisages the Anglosphere as roughly coterminous with the United States and the expanse of the midtwentieth century British empire, though most weight is typically placed on the US and India. Call this the 'empire' model. Interest in deepening relations with the US is unsurprising given the entrenched Atlanticism of the British political elite. Some Anglosphere exponents, including John Redwood (2001), even argue for British participation in the North American Free Trade Agreement. The renewed interest in the Commonwealth is more striking. Ideas about the Commonwealth, and in particular India, played a notable though ambiguous role in the Brexit campaign, and continue to generate interest among some Brexiteers (Namusoke, 2016; Murphy, 2016, Ch. 8).

The second model defines the Anglosphere as a community or association comprised of the United Kingdom and a select group of its former settler colonies. It tends to be centred on a "core" of the United Kingdom, the United States, Canada, Australia and New Zealand. Some of its devotees are 
open to the possible future inclusion of other states (including India, Ireland and Singapore), though they are usually reluctant to provide any detail or a timeline. Call this the "settler colonial model." Thus in 1999 Robert Conquest suggested an "Anglo-Oceanic" political association "weaker than a federation, but stronger than an alliance" (Conquest, 2000, 225). A few months later Margaret Thatcher endorsed Conquest's vision. "Unlike the European Union ... an English-Speaking Union would be united by those deeper values - our common moral commitments to democracy and freedom tied together by our common language" (Thatcher, 1999). In the early 2000s this broad conception of the Anglosphere drew the attention of some senior politicians, including Tony Blair, Gordon Brown, and John Howard (Kenny \& Pearce, 2018, ch. 6). Daniel Hannan, a leading Brexit campaigner, is amongst its most prominent contemporary exponents. He suggests a world-historical role for the people who "invented freedom": “As a devolved network of allied nations, the Anglosphere might yet exert its benign pull on the rest of the century. Without that pull, the future looks greyer and colder" (Hannan, 2013, 17-18). The final model confines membership to the United Kingdom, Australia, Canada, and New Zealand. Call this the "imperial federal model." It forms the basis for discussion of CANZUK.

A further important issue concerns the extent of Anglosphere institutionalization: the degree to which projects entail the creation of new institutions, or the deepening of existing ones. Plans range from those requiring little further development through to the formation of legal, economic, and political institutions to bind the constituent states together. On this issue, there is considerable variation between supporters of each model. Anchoring one end of the spectrum are minimalists who favour extremely loose and flexible arrangements - more network than polity, as exemplified by the American entrepreneur and author James C. Bennett (2004) $)^{\mathrm{iii}}$ - while on the other end are maximalists who want to fuse the existing states into a federal or confederal association (e.g. Conquest, 2005, 221-235). The same divisions emerge among CANZUKers. Many focus on securing trade deals, changes in visa 
regimes, and security co-operation, while the more ambitious argue for the creation of fresh political institutions. The most radical plans imagine a new transoceanic state.

The Anglosphere has typically been defined both positively and negatively. The positive case is built through reference to shared language, history, values, and culture, and a claim - sometimes explicit, sometimes implicit - about the superiority of the political and economic models found throughout the Anglosphere. The core countries are English-speaking, predominantly Protestant, liberal, democratic, and pro-free market. Negatively, the Anglosphere is often pitched as an alternative to European institutions, and especially the European Union. Many Anglosphere devotees regard Britain's accession to the EEC in 1973 as both a monumental mistake and an act of treachery - a mistake because it ignored the weakness of the European project; treachery, because it spurned the true British "kith and kin.” Hence Boris Johnson’s 2013 criticism that “we betrayed our relationships with Commonwealth countries such as Australia and New Zealand” (Johnson, 2013; also see Wellings and Baxnendale 2015). Anglosphere discourse during the last couple of decades has been pervaded by a sense of historical injustice, and of the need to correct a tragic mistake. Since the late 1990s a parade of conservative Eurosceptics have lionized the Anglosphere, in one form or another, as the best future for Britain, including Aaron Banks, John Bender, Bill Cash, David Davis, Nigel Farage, Frederick Forsyth, Liam Fox, David Willetts, Michael Gove, Daniel Hannan, Michael Howard, Owen Paterson, Boris Johnson, William Rees-Mogg, Norman Lamont, Austin Mitchell, John Redwood, Andrew Roberts, and Norman Tebbit (Kenny \& Pearce, 2018, ch. 5-6). The same period coincided with the rise of conservative governments in Australia, Canada, New Zealand, and the USA, which furnished a “sympathetic international milieu” for Anglosphere discourse (Kenny \& Pearce, 2018, 133).

The term CANZUK can be traced back to the 1960s (McIntyre, 1966, 275), though it did not enter popular usage at the time. It re-emerged in 2016. The first to use it in the mainstream media was 
Bennett, in a USA Today op-ed published hours after the Brexit vote (Bennett, 2016b). He also penned the first programmatic book on the subject, A Time For Audacity, which appeared in both pre- and post-EU referendum editions. Bennett conceives of the CANZUK Union — which he also calls the "Commonwealth Union" and the "Commonwealth Federation" - as a "political federation having the character of a state, consisting of Canada, Australia, New Zealand, and the United Kingdom, and possibly other Commonwealth Realms” (Bennett, 2016a). In part, the book reiterates key aspects of his earlier influential account of the Anglosphere, suggesting that revolutions in transportation and communication - above all cheap air travel and the Internet - have shrunk the globe, facilitating integration between like-minded groups. The idea is not just to deepen economic and political connections between existing allies, but to create a new form of state distributed over oceanic distances. A polity on this scale, and of this type, would be unprecedented in world history. Attentive to obvious criticisms, Bennett supplies answers to a catalogue of questions, including: “Isn’t this just re-assembling the British Empire?’, ‘Wouldn’t the Commonwealth Union just be a 'White Man's Club'?," and "What About the USA?" He also draws on the imaginative resources of speculative fiction, sketching “A Day in Life of the Union 2036," an account of CANZUK's future told from the perspective of eleven characters.

The earliest prominent adopters of the CANZUK argument in Britain were Andrew Lilico, a Tory think-tanker and economist, who served as an advisor to the Leave Campaign, and the historian and journalist Andrew Roberts. Writing in the Canadian Financial Post in August 2016, Lilico outlined his vision for a "close geopolitical alliance" that would "allow its peoples to assert their very similar culture and values in the world as a major global player instead of secondary regional players ultimately subservient to others....When CANZUK speaks, all would listen. Shall we try?” (Lilico, 2016). ${ }^{\text {iv }}$ A month later Roberts, long an ardent supporter of the Anglosphere opined in The Daily Telegraph: "Of all the many splendid opportunities provided by the British people's heroic Brexit vote, perhaps the 
greatest is the resuscitation of the idea of a CANZUK Union." Citing Bennett's Audacity, he argued that " $[t]$ o pick up where we left off in 1973," we need "a new federation based upon free trade, free movement of peoples, mutual defence, and a limited but effective confederal political structure." This federation would be "one of the global great powers" and a "pillar of Western civilisation" (Roberts, 2016).

Claims about shared identity are central to all visions of the Anglosphere. The basic argument is that the social and cultural similarities between the countries provide a feasible basis for establishing and strengthening political and economic institutions. Identity is assigned priority over geography. Hannan often claims that while Europe may be physically proximate to Britain, the Anglosphere countries are closer in every other respect. "Why should we allow accident of geography to trump ties of language and law, habit and history, culture and kinship?" (Hannan, 2016). For Roberts, CANZUK "will be more like the successful federations the English-speaking world has known, such as Canada and Australia," because they possess "the prerequisites for forming a parliament and government that could exercise control over their bureaucracies," unlike the "uncontrollable quangos of Brussels."

Sir Roger Scruton's famous dictum that 'A nation-state is the widest span at which it is possible to be meaningfully good' can be inverted with no loss of truth, for if there are a set a peoples who effectively share an idea of what public good is, then they will probably be candidates for a state, at least a federal one (Roberts, 2016).

Geography is washed away in a techno-utopian dream of the immaterial.

Lilico, meanwhile, often describes CANZUK as “intimate.” It does not matter that as trading partners the US, EU, and even China, will all dwarf CANZUK, so long as the latter maintain "a common sense of "us"' (Lilico, 2017). He contends that this collective identity and purpose differentiates CANZUK from the other two Anglosphere models. The United States is simply too dominant, too large, and its 
constitution is insufficiently similar, for inclusion. As with Roberts, Lilico suggests that the United States and CANZUK would be close allies, not part of the same overarching political community. "CANZUK would be a partner, complement and occasional competitor to the US. The US cannot be in" (Lilico, 2016). As has traditionally been the case in arguments of this kind, the other former territories of the British Empire would also be excluded. India, for example, has too much "historical baggage" with the UK - a characteristic example of the euphemisms that Anglosphere boosters adopt when discussing histories of violent conquest, exploitation, and domination - while the “Queen's Realms," a group of sixteen countries ranging from Antigua and Barbuda to Tuvalu, are too poor and have crime rates that are too high (Ibid.) Select Queen's Realms could join the club if they adopt its rules; that is, "if they can raise their GDP per capita and reduce their murder rates" - "in some decades time." They are condemned to the waiting room of history (Chakrabarty, 2000).

\section{Networking CANZUK}

CANZUK advocacy is a network phenomenon, albeit of a rather etiolated kind. In the scholarly literature, transnational advocacy networks refer to "actors working internationally on an issue, who are bound together by shared values, a common discourse, and dense exchanges of information and services” (Keck \& Sikkink, 1998, 89). Individual actors include high-profile advocates like Bennett, Roberts, and Lilico, who share values and a discourse, even if they do not communicate frequently with each other. Importantly, they tend to conceive of CANZUK as a long-term process, hence the preference by some for the term "CANZUK Uniting” over "the CANZUK Union.",

There are three organisations dedicated to CANZUK advocacy: "CANZUK International," "the CANZUK campaign," and "CANZUK Uniting." CANZUK International, established in January 2017, builds on the now-defunct Commonwealth Freedom of Movement Organisation. Standing 
behind both is James Skinner, a Vancouver-based paralegal, who in 2015 launched an online petition for freedom of movement between the four CANZUK nations. By mid-2018 this had 250,000 signatures, and Skinner plans to submit it to Members of Parliament and Senators in the four respective countries. The model for this deal is the Trans-Tasman Travel Arrangement, signed in 1973, that fateful year in the history of the "English-speaking peoples." In line with the proposals described in the previous section, CANZUK International is also calling for a comprehensive multilateral free trade agreement, for greater intelligence, defence, and foreign policy cooperation, and for expanding the rights of CANZUK citizens in each others' countries. CANZUK International claims to have staff in all four countries. The organization's advisory board includes well-connected business leaders like John Bender, who heads an investment office in London, and Sir Michael CraigCooper. Skinner's own politics are broadly conservative and Eurosceptic. Writing in September 2016, he welcomed Brexit as an opportunity to strike a Canada-UK trade agreement, citing potential increases in trade, investment and labour flows (Skinner, 2016).

Launched in July 2016, the Edinburgh-based CANZUK Campaign backs greater CANZUK cooperation in seven areas: "Trade, Mobility, Trust, Diplomacy, Security, Research and Sovereignty" (2017, Our Platform). Its plan, outlined in a mere 1200 words, consists of identifying existing international agreements and suggesting they can be applied to the CANZUK countries. "Trade," for example, is modelled on the Australia-New Zealand Closer Economic Relations (CER) agreement, while "Mobility" is modelled on the aforementioned TTTA. "Diplomacy" invokes the Nordic template, specifically the creation of common embassies à la Berlin's Nordic Embassies complex, while also noting that Canada and the UK already share properties in Baghdad, Monterrey, and Port au Prince. Although the campaign declares itself non-partisan, the language of its seven-point plan contains mostly conservative platitudes: "shared values," "efficiency and cost savings" and "parliamentary sovereignty." Such tenets, they continue, will provide "clear sovereignty safeguards," 
designed to protect against (presumably EU-like) “supranational overreach.” If upheld, they would be in tension with the more integrationist CANZUK proposals sketched by Bennett.

The third organisation is "CANZUK Uniting." Founded in 2016, this website is a "showcase for comment and analysis highlighting the affinities shared by these four countries, and the need for cooperation and partnerships between them - in both the public and private spheres." CANZUK Uniting lists the following individuals as contributors and/or members of its advisory board: Roberts, Bennett, Lilico, the disgraced Canadian former media tycoon Conrad Black, historian Jeremy Black, the editor of Quadrant (and former editor of National Review) John O'Sullivan, Canadian scholar and political adviser Michael Bonner, the editor and publisher of The New Criterion Roger Kimball, Canadian commentator Brent Cameron, and Chicago lawyer and Bennett co-author Michael J. Lotus, among others.

Several prominent politicians have also expressed interest in (minimalist) CANZUK proposals. In Canada, the list includes Andrew Scheer, Conservative prime minister-in-waiting, and his shadow foreign minister (and former minister of veteran affairs) Erin O’Toole. On August 25, 2018, Canada's Conservatives hosted Hannan at their party's policy convention in Halifax. They adopted a bullet points-styled resolution for realizing the following objectives "among CANZUK countries": "a) free trade in goods/services; b) Visa-free labour/leisure mobility for citizens, including retirement relocation; c) reciprocal healthcare agreement modeled on existing AU/NZ/UK bilaterals; d) increased consumer choice/protection for travel; and e) security coordination." vi The party may decide to campaign to promote this idea further in the run-up to the next federal election. Should the newly introduced U.S.-Mexico-Canada Agreement, or USMCA, falter, the Conservatives might also advocate for Britain to join a new North American trade agreement--an idea Conrad Black floated over twenty 
years ago in report he wrote for the Centre for Policy Studies, a think tank founded by Thatcher (Black, 1998).

In Australia, former Prime Minister Abbot authored a foreword for a 2017 Free Enterprise Group paper penned by James Cleverly and Tim Hewish, "Reconnecting with the Commonwealth: The UK's free trade opportunities." In it, Abbot endorsed “free-trade agreements with economically advanced Commonwealth countries." As he put it: "The best way to ensure that free trade has few losers, even in the short term, is to begin with much freer trade between like-minded countries with comparable standards of living." Alexander Downer, until recently Australian High Commissioner to the UK, and now Chair of Trustees of the influential Conservative think tank Policy Exchange, and James Paterson, Liberal Senator for Victoria, likewise support the agenda outlined by Abbott (Downer, 2016; Paterson, 2017). In New Zealand, CANZUK is championed only on the political fringe - by David Seymour of the Act New Zealand Party (Seymour, 2016). However, former Prime Minister John Key can be described as CANZUK-curious.

Individuals outside Anglosphere countries occasionally play a role in this advocacy network. A case in point is the French demographer Emmanuel Todd, whose theories on the distinctiveness and social effects of "Anglo-Saxon family structures" have become de rigeur among Anglosphere enthusiasts (Todd, 1985, 54-61). Todd recently embraced the notion of the Anglosphere to describe what he sees as the "heart of modern history in the years 1700-2015" (Todd, 2017, 37-39). Todd's writings in turn are informed by the arguments of the historical anthropologist Alan Macfarlane, another key source of Anglospheric inspiration. Hannan's tract, Inventing Freedom, bears the imprint of Macfarlane's work, while Hannan's ideas have influenced Scheer (Geddes, 2017).

The CANZUK advocacy network further constitutes itself as a transnational object via commissioned surveys. The trend was set in 2015 with a YouGov survey that found that UK citizens regard Canada, 
Australia, and New Zealand, as the most desirable free movement partners, with 58\% in favour and $19 \%$ against. ${ }^{\text {vii }}$ Subsequent polls have yielded similar results. One of the main drivers of this type of advocacy is the aforementioned Tim Hewish, who in 2015 oversaw the merger of his conservative Eurosceptic think tank Commonwealth Exchange with the venerable Royal Commonwealth Society, becoming the latter's director of policy research (Murphy, 2017, 50-1). The Society's director, Michael Lake, is also notable in this context, for in February 2017 he inaugurated the society's American branch by stating the ambition to eventually bring the US into the Commonwealth as an "associate member." What hastened this extraordinary move was the election of Donald Trump, a self-professed (though highly selective) Anglophile, together with "the slightly dangerous but great fun opportunity that the 'Bad Boys of Brexit' offered"' (Sherlock, 2017).

CANZUK advocacy organisations, the Free Enterprise Group, and the Royal Commonwealth Society, are nodes in a larger network of think tanks that includes the Institute of Economic Affairs, the Adam Smith Institute, the Heritage Foundation, the Cato Institute, the American Enterprise Institute, Legatum, and the United Commonwealth Society (Kenny \& Pearce, 2018, 147-148). They share a dependable practice of inserting the adjective "free" in front of market, enterprise, trade, and competition, signalling an endorsement of the neoliberal agenda that has done so much to shape the political economy of the "Anglosphere" in recent decades (Kenny \& Pearce, 2018, pp. 82, 131, 161; Lawrence, Pegg and Evans, 2018). CANZUK can be seen as an institutional vehicle for helping to maintain this agenda.

\section{The Return of History}

What is remarkable about Anglosphere discourse in general - and CANZUK in particular - is how familiar it sounds. All three models were forged originally in debates over the future of the British 
empire that raged during the closing decades of the nineteenth century. CANZUK is the latest iteration of the once-popular idea of imperial federation. Of course, imperial federation and CANZUK are not identical. We concur with Michael Kenny and Nick Pearce that the meaning of the discourse wasn't fixed permanently during the late Victorian era (Kenny \& Pearce, 2018, 7). The political inflection of imperial federation and CANZUK, the breadth of support they mobilise, the demographic composition of the polities, Britain's standing in the world: all of these (and more) differ in important respects. To take just the first issue, the political appeal of ideas about settler colonial (re)unification has narrowed considerably during the last century and a half. Imperial Federation originally attracted many liberals, while also enthusing a range of Labour figures, including Keir Hardie. Hugh Gaitskell and Harold Wilson, among others, were as keen on the "old Commonwealth" as their conservative counterparts (Kenny \& Pearce, 2018, 177-178). The Anglosphere of today is largely a politically monotone project, rendering its appeal far more limited.

Our point is a different one. It is essential, we suggest, to acknowledge the imperial roots of the idea, both because such recognition situates CANZUK in the history of British political ideology, highlighting its notable precursors and its evolution over time, and because it helps to explain its magnetic appeal to some, its fierce rejection by others, and its general lack of salience. In particular, it explains why it is frequently seen by critics as a racialized project, a reincarnation of the old "white" colonial world. Although the imperial origins of the idea do not determine its meaning, they do condition it, shaping the reception of CANZUK projects. ${ }^{\text {viii }}$ Proponents of CANZUK cannot escape this troubling history, however hard they might try. To imagine otherwise is politically myopic.

It was during the 1880s and 1890s, in particular, that plans to consolidate the settler empire assumed a central position in British political argument (and a much more limited one in the settler colonies). Many leading thinkers, politicians, journalists, and imperial administrators, obsessed over how best to 
organise "Greater Britain." "Imperial federation" encompassed adherents of a broad spectrum of positions, some complementary, others contradictory. The Imperial Federation League (IFL) was formed in 1884 to propagate a vision of settler colonial co-operation and unification. It focused principally on recalibrating relations between Britain, Australia, Canada and New Zealand, though concerns about the possible inclusion of the United States and Ireland were also conspicuous. British imperial territories in South Asia, the Caribbean, and Africa were largely ignored, although it was occasionally suggested that at some unspecified future date, they might warrant inclusion, once they had reached the requisite level of "civilization," and even then they were to be assigned subordinate status. The discourse of imperial federation thus reinforced the dominant racialised conception of empire, insisting on the distinctiveness and superiority of the "core" white settler colonies.

From the outset the movement was riven with discord over how best to understand the ideal arrangement of the imperial system. There were three basic models in circulation. The least ambitious called for strengthening existing connections between Britain and its settler colonies, emphasizing the depth of the cultural ties, and shared economic and strategic interests, while rejecting calls for deeper unification. This model ultimately won out, insofar as the colonies moved from the margins to near the centre of British strategic and economic calculations in the early twentieth century. Another group called for the creation of a new system of imperial government, such that representatives from the various colonies would be elected to (or serve in some other capacity in) a reformed legislature. The plans differed over whether this would necessitate the modification of the existing Parliament, or whether a wholly new structure was required, but the basic idea was familiar: citizens (subjects) of the imperial polity should be represented in the legislative bodies that made decisions about their collective fate. This was the latest iteration of an idea that could be traced back to at least the eighteenth century. The third model was the most ambitious, its advocates endorsing variations on the theme of political unification, from confederation through to the creation of a federal state. (As with the current 
Anglosphere debates, there was much slippage between ideas of confederation and federation). All projects for imperial federation were premised on the importance of shared language, history, and culture - often characterised in terms of "race" - as the necessary social foundation for new political and economic institutions.

Like their heirs today, advocates of imperial federation indulged in techno-utopian fantasies, premising their arguments on the radical political and economic opportunities fostered by technological change. The development of the ocean-traversing steam ship, and above all electrical telegraphy, altered perceptions of time and space. As the historian and politician James Bryce proclaimed, "[n]o such means of gathering, diffusing, and concentrating public opinion, of quickening its formation and strengthening its action, had ever been dreamt of before our own time” (Bryce, 1891, 19). The result, wrote Francis de Winton, the President of the Geographical Section of the British Association, was “an extraordinary condition of contactiveness" (de Winton, 1889, 621). Geography, it was boasted, had been transcended. "Contactiveness" meant that new types of political communities and economic relationships were possible, and in particular, that ocean-spanning political associations could be built. As the historian J. R. Seeley wrote in 1883: "These new conditions ... make it ... possible actually to realise the old utopia of a Greater Britain, and at the same time they make it almost necessary to do so" (Seeley, 1904, 74). The main bar to union, imperial federalists argued, was not geographical distance, nor lack of appropriate communications and transport technologies, nor the absence of shared identity or interests. Instead, it was political will. Campaigning organisations were formed, pamphlets written, rousing speeches delivered, networks of like-minded individuals established, scholars, politicians, and business leaders recruited to the cause - all with the aim of shifting public (and in particular elite) opinion. Literary fiction was put in the service of political ideology, with a steady stream novels published in the late nineteenth century imagining a future world lead by a united 
"Anglo-Saxon" polity. Indeed this was a key strand in the emergence of science fiction as a literary genre (Bell, 2020). Bennett's foray into speculative fiction as political advocacy has a long pedigree. ${ }^{\text {ix }}$

Imperial federalists disagreed over geographical scope and degree of institutionalisation. Nearly all of them limited the proposed polity to the "white" empire, a core of settler states regarded as of equivalent "civilizational" standing. The United States presented one obvious challenge. Just as Anglosphere enthusiasts lament the rupture of 1973, so imperial federalists routinely mourned the eighteenthcentury split with the United States. Some saw the US as a necessary part of any viable imperial polity, though most rejected this as politically naïve and constitutionally illiterate, recognising that as a vast independent state it was unlikely to want incorporation into a (con)federation (Palen, 2016, ch 8). Nevertheless, many imperial federalists harboured dreams of future Anglo-American reunification (Bell, 2016). Union was not disavowed, so much as deferred. In the meantime, imperial federalists argued frequently that Greater Britain and the United States should co-operate closely. Imperial federation was thus nested within a wider vision of the English-speaking peoples. Ireland presented another problem. Some imperial federalists, including Bryce, saw the machinery of federation as a solution to both the Home Rule crisis and the problem of imperial organisation (Harvie, 1976). Most, however, were adamant that Ireland should not be incorporated: it was either too poor, or too rebellious, or too alien - whether in terms of religion, mores, institutions, or race - to warrant inclusion. The same reasoning was employed to exclude the rest of the empire.

The imperial federalists also split on questions of economic policy and defence, issues that eventually tore the movement apart. For many, the idea of federation was principally economic. Some called for the creation of a Zollverein, others a system of preferential tariffs, while others still advocated a vision of imperial federation based on free trade (Howe, 1998, 213-222). In 1903 Joseph Chamberlain launched his doomed campaign for imperial tariff reform. Rather than a Zollverein - an idea he had 
earlier endorsed - he called for a system of reciprocal tariffs that would entrench free trade between the members while insulating them from outside competition. While the free traders won the day, the battle convulsed the Tory Party during the Edwardian era and helped diminish support for imperial federation. But advocacy of preference never disappeared. Indeed it was enacted in 1932 and lasted, in one form or another, until Britain joined the EEC (Kenny \& Pearce, 2018, ch.3). Other imperial federalists emphasised imperial defence, insisting that the responsibilities should be shared more equitably among members of the proposed union.

The movement for imperial federation succeeded insofar as it helped to shift elite British attention towards the significance of the settler colonies. It formed part of a transnational drive to secure and stabilise "white" rule globally, the chief practical manifestation of which was the erection of racialized immigration controls (Lake \& Reynolds, 2007). But they lost the battle to bring about significant institutional change. Plans for formal union fell flat. While the federalists managed to convince a significant number of senior politicians, they failed to gain enough support to enact new legislation, and opinion in the settler colonies - with some limited exceptions - was opposed to further integration with Britain, happy as many were to remain part of the empire. This reluctance to cede their quasiautonomy was repeated when the issue re-emerged at various points during the ensuing century. Although the first phase of debate was largely exhausted by the outbreak of war in 1914, ideas about settler colonial integration persisted through the twentieth century, their popularity spiking at particular moments (Kenny \& Pearce, 2018, ch. 4). As the United States grew ever-more powerful, and British influence began to wane, enthusiasm for imperial federation faded, and the wider conception of the "English-speaking peoples," a fusion of the United States and Greater Britain, gained support. In 1946, Churchill called for "the fraternal association of the English-speaking peoples" (Vucetic, 2017). But he was fated to watch over the initial dissolution of the empire, and the beginning of the end for the "kith and kin" project. While the vocabulary evolved over time, with 
"Anglo-Saxon race" morphing into "English-speaking peoples" and now the "Anglosphere," most of the basic ideas have not. Today we hear a reheated version of arguments forged when Victoria reigned.

\section{The Romance of CANZUK}

Like the idea of the Anglosphere, CANZUK has had its share of critics. In the early 2000s, Michael Ignatieff dismissed Conquest's proposal as little more than a "romantic illusion" (Ignatieff, 2000). A steady drumbeat of criticism has been maintained ever since. Sceptics usually suggest that proposals for uniting English-speaking polities are both fanciful and politically reactionary: fanciful because they advocate policies that are thoroughly unrealistic; reactionary because CANZUK represents a return to an old imperial vision.

Thus far, little about CANZUK advocacy spells success. ${ }^{x}$ As an assemblage of grassroots initiatives, it operates with little money or technical expertise. The network remains concentrated on simple websites and social media accounts that generate content and analysis, much of it done by anonymous volunteers. The lack of political salience is evident. While several senior politicians have endorsed free trade and movement among some or all CANZUK states, none of them have committed to any detailed policies. Indeed support for the former is compatible with a thorough rejection of what makes CANZUK distinctive as a project - bromides about the value of the Anglosphere, and the need for further co-operation between already-friendly states, fall far short of an endorsement of a political or economic association. As for media salience, CANZUK tends to be covered primarily as a curiosity. Skinner's freedom of movement petition is a case in point. Although it received coverage by prominent broadcasters and newspapers in all four CANZUK countries - including ABC, BBC, $\mathrm{CBC}$, The National Post, and TVO - this has been superficial and fleeting. ${ }^{\mathrm{xi}}$ 
Public policy communities remain largely unpersuaded by the benefits of CANZUK. Take the proposed trade pact, an embryo of which some see in the May government's decision to explore free trade deal options with Australia, New Zealand, and Canada. On the surface, this is good news for CANZUK supporters. But if we follow gravity models in economics - studies that point to an outsized negative effect of geographic distance on trade - we can appreciate why Australian exports to Britain have for decades hovered below two percent of its total outgoing trade and why only for New Zealand would a CANZUK pact count as "the most important" (Ravenhill \& Heubner, 2019). In part, this explains why during the Brexit campaign, the leaders of all of the CANZUK countries supported Britain remaining in the EU. They do not see the huge benefits professed by CANZUKers. While the coming years may in fact see the aforementioned Canada-UK trade agreement and similar deals, they are unlikely to make a substantial difference to existing levels of trade.

A CANZUK defence pact is even less likely. It is true that institutions such as the Five Eyes and ABCANZ demonstrate the extensive and durable security co-operation between Australia, Canada, New Zealand, and the UK (Legrand, 2019; Vucetic, 2019). However, this also means that such a pact would function only if the US were to support it logistically and politically - hardly an endorsement of Roberts' vision of CANZUK as "one of the global great powers." Furthermore, it is illusory to think that an alliance with Britain would ever again become Australia's main strategic priority, just as it is illusory to expect that Canada and the UK would re-orient their defence postures away from the Atlantic and towards the Asia-Pacific region.

The other major criticism of CANZUK is that it is politically reactionary, a racialized throwback to the days of the British empire (Shaw, 2008, 127; Murphy, 2017, Ch.8). A recent editorial in The Globe $\ll$ Mail, a leading Canadian newspaper, exemplifies this position. It noted that despite much talk about the post-Brexit significance of the Commonwealth, the attention of "[p]arts of the British right" has 
largely been focused on the old settler colonies. "It's a funny thing ... These Tory visionaries seem most enamoured of ex-Dominions where white people predominate. There's even a silly name Canzuk - for this bloc-within-a-bloc" (Globe \& Mail, 2018). And yet, the editorial continued, the dreams of both a reanimated Commonwealth and of CANZUK are little more than "a fantasy." There is simply no appetite for them, either in the former Dominions or those "countries with a harsher and more recent colonial history." Attempts to revivify old imperial ties as the basis for British foreign and trade policy are both hopeless and smack of "neo-colonialism” (Globe \& Mail, 2018).

The leading CANZUKers recognise that "historical baggage" is the hardest framing challenge. Accordingly, many of them stress novelty and discontinuity. Bennett has always argued that his projects for English-speaking unification are non-hierarchical and "precisely the reverse" of empire (Bennett, 2007). Lilico, meanwhile, contends that CANZUK is "something completely new," rather than a revival of the imperial preferential trading system or "some reheated latter-day British Empire." ${ }^{\text {xii }}$ Such claims disregard history. The linkages between past and present ideas are clear -what is most striking is how little about CANZUK is new. Asserting that CANZUK is not a reheated version of the Victorian Empire is a red-herring. After all, it was commonplace in the late nineteenth century to deny that imperial federation designated the empire as a whole. It was "fundamental," Seeley proclaimed, to recognise that "our [settler colonial] Empire is not an Empire at all in the ordinary sense of the word" (Seeley, 1904, 51). Empire, he suggested, was an appropriate term for Britain's relationship with India, not with Canada and Australia. CANZUK disavowals of imperialism - as it is usually understood - are thus both correct and irrelevant. It is a reheated version of a specific settler colonial vision.

Virtually all CANZUK supporters stress the inclusive, multicultural character of CANZUK societies and CANZUK supporters. (In doing so, they present a rose-tinted view of the racial politics of 
CANZUK societies, all of which continue to suffer from structural forms of racism). But they cannot transcend the imperial history that originally furnished projects of settler colonial unity -projects that buttressed the creation of a "white man's world" (Lake and Reynolds, 2008; Schwartz, 2011). CANZUK is the latest variant of a long line of projects seeking to consolidate the British settler empire, projects that were until deep into the second half of the twentieth century justified in explicitly racist terms, as variations on the theme of white supremacism. This history invariably shapes interpretations of CANZUK, whatever the intentions behind it. Hence the scepticism of the Globe \& Mail editorial. And hence Philip Murphy's argument that elements of the Brexit campaign sought "to revive an older mythology of white-British racial solidarity dating from the early decades of the twentieth century" (Murphy, 2017, 198). It is naïve to imagine that this history can be transcended by simply asserting its irrelevance. ${ }^{\text {xii }}$ CANZUK supporters likewise struggle to address questions of hierarchy and of coloniality as a present condition. Indeed, while they boast about the wealth and resources that make "core" English-speaking states worthy of unity today, they tend to ignore how that wealth accumulation was predicated on imperial processes that included economic and ecological devastation, the creation of enduring divisions and inequalities, and widespread violence, including the mass killing of indigenous populations. CANZUK societies still live with the consequences of this history. It cannot be wished away.

Denying the clear historical echoes of the idea also sits awkwardly with the enthusiasm for British imperialism expressed by other leading CANZUKers. Roberts, for example, contends that CANZUK is modelled on "the dream of early 20th century giants such as Joseph Chamberlain" (Roberts, 2016). A proud defender of British imperialism, he has attacked "politically correct" expressions of "colonial guilt," maintaining that the British should celebrate their imperial deeds (Roberts, 2013). Such claims have long been popular among advocates of the wider Anglosphere. Niall Ferguson made a name for himself celebrating the British empire and its legacy. For Hannan, Britain's imperial identity was 
fundamentally liberal and a valuable "antibody against the infections of slavery and dictatorship"; given that "the independence struggles have almost faded from memory," the Anglosphere can be promoted without fuss (Hannah, 2013a, chs. 7, 9). Johnson has not hidden his admiration for the empire. "Africa may be a blot, but it is not a blot upon our conscience. The problem is not that we were once in charge, but that we are not in charge any more" (Johnson, 2002). Although he later apologised for this remark, there is little sign that he rejects this kind of neoimperial posturing. While not all advocates of CANZUK and the Anglosphere celebrate the British empire, the fact that some of its most highprofile supports do hinders the case for enacting a radical break with the past. It serves to highlight the continuities in sensibility, ideas, and proposals.

CANZUK then, is at once new and old. Although it has (re)emerged in the wake of Brexit, its conceptual roots, and many of its animating concerns and ideas, can be traced to the imperial debates of the late nineteenth and early twentieth century. Then, as now, dreams of settler colonial unity reveal far more about the ideological practices of English-speaking elites than they do about economic and geopolitical realities. CANZUK serves as a window into the assumptions, interests, and dreams, of some of those seeking to maintain Britain's - or the "English-speaking peoples" - position as a major global power. 


\section{References}

Adler-Nissen, R., C. Galpin, and B. Rosamond. (2017) Performing Brexit: How a Post-Brexit World Is Imagined Outside the United Kingdom.” British Journal of Politics and International Relations 19 (3): 573-591.

Bell, D. (2020). Dreamworlds of race: Empire, utopia, and the fate of Anglo-America. Princeton: Princeton University Press.

Bell, D. (2019). Anglospheres: Empire Redivivus? In Andrew Mycock and Ben Wellings, eds, The Anglosphere. Oxford: Oxford University Press.

Bell, D. (2016). Reordering the world: essays on liberalism and empire. Princeton: Princeton University Press. Bennett, J. (2016a) A time for audacity: New options beyond Europe. Pole to Pole.

Bennett, J. (2016b) Brexit boosts "CANZUK" replacement for the European Union. USA Today. Bennett, J. (2004) The Anglosphere challenge: Why the English-speaking nations will lead the way in the twentyfirst century. Lanham: Rowman and Littlefield, 2004.

Black, C. (1998). Britain's Final Choice: Europe or America? Centre for Policy Studies. Retrieved from https://www.cps.org.uk/files/reports/original/111027150000-BritainsFinalChoice1998.pdf Bryce, J. (1891). An age of discontent. The Contemporary Review. Vol 59, 14 CANZUK. (2017) Our platform: Campaigning for stronger CANZUK ties. Retrieved from https://www.canzuk.org/our platform campaigning for stronger canzuk ties.php

Cleverly, J \& T Hewish. (2017) "Reconnecting with the Commonwealth: the UK's free trade opportunities," Free Enterprise Group, paper, Jan. 2017, 30 pgs. https://gallery.mailchimp.com/708e119fa74cd33e6a28f949a/files/FEG Commonwealth Trade w $\underline{\text { eb.pdf }}$

Conquest, R. 'Toward an English speaking union', The National Interest, Fall 1999.

Conquest, R. (2000) Reflections on a ravaged century. New York, W. W. Norton. 
Conquest, R. (2005) The dragons of expectation: Reality and delusion in the course of history. New York, W. W. Norton.

Chakrabarty, D. (2000) Provincialising Europe: postcolonial thought and historical difference Princeton: Princeton University Press.

de Winton, F. (1889) “Address.” Proceedings of the Royal Geographical Society, 11, 621.

Daddow, O. (2018) Brexit and Britain's Role in the World. In P. Diamond, P. Nedergaard and B. Rosamond, eds. The Routledge Handbook of the Politics of Brexit. Abingdon: Routledge Handbooks Online 04 May 2018 , Retrieved on 22 June 2018 , from https://www.routledgehandbooks.com/doi/10.4324/9781315169613-17

Downer, A. (2016) Australia was wounded when Britain joined the EU. Now we can make things right - as partners. The Telegraph. Retrieved from http://www.telegraph.co.uk/news/2016/12/17/australia-wounded-britain-joined-eu-now-canmake-things-right

Geddes, J. (2017) Andrew Scheer, the conservative party's folksy unifier. Maclean's. Retrieved from http://www.macleans.ca/politics/ottawa/andrew-scheer-leader-conservative-party-of-canadaprofile/

Globe \& Mail. (2018) With Brexit looming, Britain suddenly remembers the commonwealth.

Retrieved from https://www.theglobeandmail.com/opinion/editorials/article-globe-editorial-withbrexit-looming-britain-suddenly-remembers-the/

Hannan, D. (2013) Inventing freedom: How the English-speaking peoples made the modern world. New York, Broadside.

Hannan, D. (2016) Free Britain to trade with the world. The Financial Times. Retrieved from https://www.ft.com/content/6d4a444a-36f5-11e6-a780-b48ed7b6126f

Harvie, Christopher (1976) The lights of liberalism. London, Viking. 
Howe, A. (1998). Free trade and liberal England, 1846-1946. Oxford, Oxford University Press.

Ignatieff, M. (2000) The man who was right. New York Review of Books. Retrieved from

http://www.nybooks.com/articles/2000/03/23/the-man-who-was-right/

Johnson, B. (2002) Cancel the guilt trip: Africa is a mess, but it is simply not credible to blame colonialism. The Spectator.

Johnson, B. (2013) The Aussies are just like us, so let's stop kicking them out. The Telegraph, Aug 25.

Keck, M. \& Sikkink, K. (1998) Activists beyond borders: Advocacy networks in international politics. Ithaca NY, Cornell University Press.

Kenny, M., Pearce, N. (2018) Shadows of empire: The anglosphere in British politics. Cambridge, Polity Press.

Lake, M. \& Reynolds, H. (2007) Drawing the global color line: white men's countries and the international challenge of racial equality. Cambridge, Cambridge University Press.

Lawrence, Felicity, David Pegg, and Rob Evans, "Rightwing thinktanks unveil radical plan for USUK Brexit trade deal," The Guardian, 18 September 2018.

https://amp.theguardian.com/politics/2018/sep/18/rightwing-thinktanks-unveil-radical-plan-for$\underline{\text { us-uk-brexit-trade-deal-nhs }}$

Legrand, T. (2019), “Anglosphere Security Networks: Constitutive Reduction and International Cooperation," In Andrew Mycock and Ben Wellings, eds, The Anglosphere: Continuity, Dissonance and Location. Oxford: Oxford University Press, ch. 4.

Lilico, A. (2016) From Brexit to CANZUK: a call from Britain to team up with Canada, Australia and New Zealand. Financial Post. Retrieved from http://business.financialpost.com/opinion/frombrexit-to-canzuk-a-call-from-britain-to-team-up-with-canada-australia-and-new-zealand

Lilico, A. (2017) How to choose our new geopolitical partners. Reaction.Life. Retrieved from https://reaction.life/choose-new-geopolitical-partners/ 
Lilico, 'What other countries might eventually join CANZUK?', 10 March 2017, https://www.canzuk.co.uk/single-post/2017/03/10/Lilico-What-other-countries-might-eventuallyjoin-CANZUK.

McIntyre, W. D. (1966). Colonies into Commonwealth. London, Blandford

Namusoke, E. (2016) A Divided Family: Race, the Commonwealth and Brexit. The Round Table. Vol 105(5), 463-476.

Paterson, J. (2017) Let's fold UK and Canada into the closer economic relations treaty. Financial Review. Retrieved from http://www.afr.com/opinion/columnists/lets-fold-uk-and-canada-into-thecloser-economic-relations-treaty-20170827-gy4zm1

Palen, M. (2016) The “Conspiracy” of Free Trade: The Anglo-American Struggle Over Empire and Economic

Globalization, 1846-1896. Cambridge, Cambridge University Press.

Ravenhill, J. \& Heubner, G. (2019) The political economy of the Anglosphere. In Andrew Mycock and Ben Wellings, eds, The Anglosphere. Oxford: Oxford University Press.

Redwood, J. (2001). Stars and strife: The coming conflicts between the USA and the European Union. Basingstoke, Palgrave.

Roberts, A. (2016) CANZUK: After Brexit, Canada, Australia, New Zealand and Britain can unite as a pillar of Western civilisation. Daily Telegraph. Retrieved from

http://www.telegraph.co.uk/news/2016/09/13/canzuk-after-brexit-canada-australia-new-zealandand-britain-can/

Roberts, A. (2013) 'Hideously amoral Little England has stepped through the looking glass', Daily Mail, 31 Aug.

Schwarz, Bill (2011). Memories of empire: The white man's world. Oxford: Oxford University Press. Seeley, J. (1904 [1883]) The expansion of England: two courses of lectures. London, Macmillan. 
Seymour, D. (2016) ACT proposes free movement with Britain, Australia, and Canada. Act NZ.

Retrieved from http://act.org.nz/act-proposes-free-movement-with-britain-australia-and-canada/

Shaw, T. (2008). Commonwealth: inter- and non-state contributions to global governance. Abdington:

Routledge.

Sherlock, R. (2017) Exclusive: United States could become an 'associate member' of the

commonwealth. The Telegraph. Retrieved from

http://www.telegraph.co.uk/news/2017/02/23/donald-trumps-love-royal-family-may-see-united$\underline{\text { states-join-commonwealth/ }}$

Skinner, J. (2016) Brexit will help to bring Britain and Canada even closer. Conservative Home.

Retrieved from https://www.conservativehome.com/platform/2016/09/james-skinner-brexit-will-

help-to-bring-britain-and-canada-even-closer.html

Thatcher, M. (1999) “The language of liberty.” [Speech] English-Speaking Union, 7th December.

Todd, E. (1985) The explanation of ideology: Family structures and social systems. New York, Blackwell.

Todd, E. (2017) Où en sommes-nous ? Une esquisse de l'histoire bumaine. Paris, Seuil.

Vucetic, S. (2011). The Anglosphere: A genealogy of a racialized identity in international relations. Palo Alto:

Stanford University Press, 2011.

Vucetic, S. (2017) The Fulton address as racial discourse. In Alan Dobson and Steve Marsh (eds.)

Churchill and the Anglo-American special relationship. London, Routledge, pp. 96-115.

Vucetic, S. (2019). The Anglosphere beyond Security. In Andrew Mycock and Ben Wellings, eds, The Anglosphere: Continuity, Dissonance and Location. Oxford: Oxford University Press, ch. 5.

Wellings, Ben \& Helen Baxendale, 'Euroscepticism and the Anglosphere: traditions and dilemmas in contemporary English nationalism', Journal of Common Market Studies 52: 1, 2015, pp. 123-39. 


\section{NOTES}

${ }^{i}$ Earlier versions of this article benefitted from the presentation at the 59th Annual Convention of the International Studies Association in San Francisco, California, April 4-7, 2018, and from the comments and criticisms by Mark Laffey, Oliver Daddow, Sean Fleming, Marc-William Palen, Robert Saunders, and two anonymous reviewers. All the usual disclaimers apply.

ii CANZUK proponents were interviewed either in person, in June 2017 in London, and/or over Twitter and email from February 2017 to September 2018. See subsequent footnotes for further details.

iii Bennett did more than anyone to popularise the term Anglosphere, though his own conception of it differs from most others in important respects, not least in its partially deterritorialised character.

${ }^{\text {iv }}$ Lilico has since written dozens of op-eds and blog posts on the topic, while vigorously promoting the idea on social media. His CANZUK is nested in a "broader and looser" Anglosphere that also includes "the Caribbean and possibly Ireland"; an "ever closer union" akin to the EU, albeit without the latter's bureaucracy and regulations; a "deep geopolitical partnership" with similarities to the "Warsaw Pact partnerships of the 1970s" (Lilico, 2017). Correspondence with Lilico over Twitter and email, February-March 2017 led us to his CANZUK posts on Reaction, https://reaction.life/author/andrew lilco/, on CANZUK Uniting https://www.canzuk.co.uk/home-1/author/ (both last accessed 12 December 2017).

v As Michael Lotus puts it: "The term CANZUK reflects a cluster of potential revisions to the relationships between the four countries." E-mail correspondence, 14 January 2018. Also from similar correspondence with Lilico in March 2016 and with Bennett, December 2017.

${ }^{\text {vi }}$ This was announced on social media only. Details are presumably forthcoming in the next federal election.

${ }^{\text {vii }}$ Compared to the equivalent scenarios involving the US (45\% for, $27 \%$ against) and the existing arrangement with the EU (46\% for, 35\% against). YouGov survey of 11-12 November 2015, cited in Lilico (2017).

viii This is also true of the wider Anglosphere discourse (Bell, 2019; Vucetic, 2019). 
ix Today, transport and communications technology, and the purported collapse of time and space, remain central, to visions of the Anglosphere. The internet, in particular, has drawn the attention of many of them, and in particular Bennett (2000) and Hannan (2013).

× According to Keck and Sikkink (1998, Introduction, 204-7), "density" refers to both the number of organizations in a network and to the strength of the connections within it. In addition to density, advocacy success further depends on the public resonance of activists' claims.

${ }^{x i}$ It is also covered by the far right outlets like The Rebel in Canada. Even if the number of signatories were to quintuple, this still pales in comparison to, for example, several anti-Brexit petitions in the UK.

xii Lilico (2016); Twitter and e-mail exchange with Lilico, March 2017.

${ }^{x i i i}$ On the need to locate debates over the Anglosphere in relation to question of public memory about empire, and the 'imperial history wars,' see Bell (2019). 